\title{
Avian Gyrovirus 2 and Avirulent Newcastle Disease Virus Coinfection in a Chicken Flock with Neurologic Symptoms and High Mortalities
}

\author{
Celia Abolnik ${ }^{\mathrm{A}}$ and Daniel B. R. Wandrag \\ Poultry Section, Department of Production Animal Studies, University of Pretoria Faculty of Veterinary Science, Private Bag X04, \\ Onderstepoort, 0110, South Africa
}

Received 3 September 2013; Accepted 31 October 2013; Published ahead of print 4 November 2013

\begin{abstract}
SUMMARY. A disease with severe neurologic symptoms caused $100 \%$ mortality in a small broiler operation in the Gauteng Province, South Africa in late March 2013. Routine diagnostic PCR testing failed to identify a possible cause of the outbreak; thus, samples were submitted for virus isolation, serology, and bacteriology. An avirulent Newcastle disease virus (NDV) strain isolated was identified as a V4-like genotype 1 strain, by DNA sequencing, with a cleavage site of ${ }^{112} \mathrm{GKQGR} \downarrow \mathrm{L}^{117}$. Real-time reverse transcription PCR identified NDV in the brain but not in cecal tonsils or pooled tracheas, spleens, lungs, and livers. A random amplification deep sequencing of a transcriptome library generated from pooled tissues produced 927,966 paired-end reads. A contig of 2,309 nucleotides was identified as a near-complete avian gyrovirus 2 (AGV2) genome. This is the first report on the African continent of AGV2, which has been reported in southern Brazil, the Netherlands, and Hong Kong thus far. A real-time PCR for AGV2 only detected the virus in the brain but not in cecal tonsils or pooled tracheas, spleens, lungs, and livers. Sequence reads also mapped to the genomes of mycoplasma, Escherichia coli, avian leukosis virus subtype J, and Marek's disease virus but excluded influenza A virus, Ornithobacterium rhinotracheale, avian rhinotracheitis virus, avian encephalomyelitis virus, and West Nile virus. Air sac swabs were positive on bacterial culture for E. coli. The possibility of a synergistic pathogenic effect between avirulent NDV and AGV2 requires further investigation.
\end{abstract}

RESUMEN. Coinfección entre el gyrovirus aviar 2 y el virus de la enfermedad de Newcastle avirulento en una parvada de pollo de engorde con signos neurológicos y alta mortalidad.

Una enfermedad con signos neurológicos graves causó una mortalidad del $100 \%$ en una operación pequeña de pollos de engorde en la provincia de Gauteng, en Sudáfrica a finales de marzo del 2013. Las pruebas rutinarias de diagnóstico por PCR no lograron identificar una posible causa del brote, por lo que las muestras fueron sometidas al aislamiento viral, serología y bacteriología. Se aisló e identificó un virus de la enfermedad de Newcastle no virulento (NDV) como una cepa similar al genotipo 1 V4, por secuenciación de ADN, en el sitio de disociación ${ }^{112} \mathrm{GKQGR} \downarrow \mathrm{L}^{117}$. Mediante un método de transcripción reversa y PCR en tiempo real se identificó la presencia del virus de Newcastle en el cerebro, pero no en las tonsilas cecales o en las muestras agrupadas de tráquea, bazo, pulmones, e hígado. Una amplificación con secuenciación profunda y aleatoria de una biblioteca de transcriptoma generada a partir de muestras agrupadas de tejidos produjo 927,966 lecturas emparejadas. Se identificó un contig de 2309 nucleótidos como un genoma casi completo de un Gyrovirus aviar 2 (AGV2). Este es el primer informe en el continente africano de la presencia del AGV2, que se ha reportado hasta el momento en el sur de Brasil, los Países Bajos y Hong Kong. Un método de PCR en tiempo real para AGV2 sólo detectó al virus en el cerebro, pero no se detectó en las tonsilas cecales, o en las muestras agrupadas de tráquea, bazos, pulmones e hígado. Las lecturas de las secuencias también se relacionaron con el genoma de mycoplasma, Escherichia coli, con el virus de la leucosis aviar subtipo J, y con el virus de la enfermedad de Marek, pero excluyó al virus de la influenza A, Ornithobacterium rhinotracheale, al virus de la rinotraqueítis aviar, al virus de la encefalomielitis aviar y al virus del Nilo Occidental. Los hisopos de sacos aéreos fueron positivos para el cultivo bacteriano de E. coli. La posibilidad de un efecto patogénico sinérgico entre el virus de Newcastle avirulento y el AGV2 requiere de más investigación.

Key words: avian gyrovirus, Newcastle disease virus, PCR, genome

Abbreviations: AGV2 = avian gyrovirus 2; ALV = avian leukosis virus; $\mathrm{CAV}=$ chicken anaemia virus; $\mathrm{Ct}=$ cycle threshold; $\mathrm{GyV} 3=$ gyrovirus 3; GyV4 = gyrovirus 4; $\mathrm{HGV}=$ human gyrovirus; $\mathrm{HI}=$ hemagglutination inhibition; MDV $=\mathrm{Marek}$ 's disease virus; $\mathrm{NDV}=$ Newcastle disease virus; $\mathrm{nt}=$ nucleotide; $\mathrm{RT}-\mathrm{PCR}=$ reverse transcription PCR

The genus Gyrovirus in the family Circoviridae comprises nonenveloped DNA viruses with icosahedral symmetry and circular, single-stranded DNA genomes of $\sim 2.3 \mathrm{~kb}$. The genus currently includes chicken anemia virus (CAV) and proposed members human gyrovirus (HGV), avian gyrovirus 2 (AGV2), gyrovirus 3 (GyV3), and gyrovirus 4 (GyV4) (3,9). Gyrovirus genomic organizations are similar: CAV, AGV2, HGV, and GyV3 encode partially overlapping proteins VP1, VP2, and VP3 as well as a putative $5^{\prime}$ untranscribed region, but GyV4 appears to lack a VP3 gene (3). CAV was first isolated in 1979 and causes an economically important and severe disease in young susceptible chickens and immunosuppression in adult birds (12); the other members of the genus are more-recent

\footnotetext{
${ }^{\mathrm{A} C}$ Corresponding author. E-mail: celia.abolnik@up.ac.za
}

discoveries. HGV-specific DNA has been detected in both healthy human skin swabs and fecal samples from patients with diarrhea $(3,11)$. AVG2 was first discovered in the sera of backyard adult chickens in southern Brazil in 2008 with symptoms of apathy, weight loss, and brain lesions (10) and subsequently in the Netherlands (5). Chu et al. (3) suggested that AGV and HGV are essentially the same virus with nucleotide homology of $>92 \%$, as they could find no phylogenetic distinction between viruses of human or chicken origin. The genomes of AGV2 and CAV are only about $40 \%$ identical (10). GyV3 and GyV4 were also discovered in human fecal samples but not on skin $(3,9)$. CAV, AGV2-HDV, and GVy4-specific DNA was detected in 14/14 and 10/14 homogenized chicken skin samples, respectively, and in 12/14 and 4/14 homogenized chicken meat samples, respectively. The chicken meat originated from local markets in Hong Kong or frozen Brazilian imports (3). 
In late March 2013, a small producer in the Gauteng Province of South Africa submitted 5 live and 10 dead 25-day-old broilers to the University of Pretoria's Poultry Reference Centre at Onderstepoort. Severe neurologic symptoms and mortalities had begun a week earlier at 28 days of age; by the time of sampling at least 500 of 1400 birds $(36 \%)$ had died and the remainder of the flock were also sick. This flock and other houses on the farm were immediately blanket spray-vaccinated with live Newcastle disease virus (NDV) Clone 30 strain and were subsequently treated for 5 days with a broadspectrum antibiotic through the drinking water. Another house of 800 21-day-old broilers displayed similar neurologic symptoms and were also treated. Despite the success of this regime in previous NDV outbreaks, all birds of both age groups died within a 2-wk period. All of these broilers had been vaccinated at the hatchery as 1day-old chicks with inactivated La Sota NDV strain, a live vaccine containing NDV and Massachusetts H120 strain infectious bronchitis virus and live infectious bursal disease virus. The birds were not vaccinated against Marek's disease virus (MDV).

Tracheal and cecal tonsil samples submitted to the Agricultural Research Council- Onderstepoort Veterinary Institute (ARC-OVI) were pooled and tested by hemi-nested reverse transcription PCR (RT-PCR), which failed to conclusively detect NDV, and the influenza A virus real-time RT-PCR results were confirmed negative (M. Romito, laboratory report); the brain samples submitted were not tested. To detect pathogens present in this case, a direct random amplification deep sequencing on pooled tissue extract approach was taken.

\section{MATERIALS AND METHODS}

Clinical and postmortem findings. On clinical examination, three of the five live birds showed signs of paresis, paralysis, and torticollis. On postmortem four of these birds showed various degrees of rhinitis, tracheitis, airsacculitis, and peritonitis. Macroscopic brain lesions were absent. Individual tissue samples were collected and sera, airsac swabs, and tissue pools were submitted for diagnostic serology, bacterial culture, and virus isolation to the University's Department of Tropical Diseases.

Random amplification deep sequencing. Total nucleic acid was extracted from a homogenized pooled tissue sample consisting of trachea, spleen, liver, lung, cecal tonsil, and brain using TriZOL LS reagent (Ambion Life Technologies, Grand Island, NY). Transcriptomic and Nextera sequence libraries were prepared as previously described (1) followed by analysis on an Illumina MiSeq sequencer at the Agricultural Research Council-Biotechnology Platform, Onderstepoort, South Africa. Data were analyzed using CLC Genomics Workbench v5.1.5 (CLC bio, Aarhus, Denmark).

Real-time PCR. AGV2 and NDV were amplified using a real-time RTPCR on the total nucleic acid samples reextracted from separate tissue pools (brains, cecal tonsils, and pooled trachea-spleen-lung-liver) using TriZOL LS reagent as before. For NDV, a primer-probe set targeting the viral polymerase gene was used (7) with the modifications described below.

Oligonucleotide primers and probes were designed for AGV2 from a conserved region in the VP2-VP3 region, a multiple sequence alignment of UP455/13 AGV2 genome (this study), and reference genomes JQ690763, NC015396, HM590588, and FR823283. The forward primer used was: AGV2_505F: 5' -GCAGTGAATTCGCGCTTAGGC$3^{\prime}$ and reverse primer: AGV2_745R: 5'-CACTGGCGTAGCCAGGTAGCG-3'; AGV2pro: 5'-GGATCCACGGGCAAGACACTAAATGCAG-3' (MGB-FAM).

Reaction mixes of a total volume of $15 \mu \mathrm{l}$ were set up using the VetMAX $^{\text {TM }}$-Plus One-Step RT-PCR Kit (Life Technologies). Reactions were comprised of $3 \mu \mathrm{l}$ of extracted nucleic acid, PCR-grade water, $2 \times$ RT-PCR buffer, $2 \times$ RT enzyme mix, $6.25 \mathrm{pMol}$ each of forward and reverse primer, and $0.75 \mathrm{pMol}$ of probe(s). Both NDV and AGV2 assays were run on a StepOnePlus ${ }^{\mathrm{TM}}$ (Life Technologies) for 1 cycle of $48 \mathrm{C}$ for $10 \mathrm{~min}$, followed by 40 cycles of $95 \mathrm{C}$ for $15 \mathrm{sec}$ and $50 \mathrm{C}$ for $45 \mathrm{sec}$ (data capture point).

Conventional NDV RT-PCR and sequencing. A 1100-bp portion of the fusion and matrix genes was amplified as previously described (2) and sent to Inqaba Biotech, Pretoria, South Africa for sequence determination. Results were analyzed as previously described (2).

\section{RESULTS}

Diagnostic test results for case UP455/13 are summarized in Table 1. Three of five birds had hemagglutination inhibition (HI) scores below the positive threshold for IBV, and two birds had HI titers of $\log _{2} 2$. For NDV HI, $1 / 5$ birds had a titer of $\log _{2} 2,3 / 5$ had high titers of $\log _{2} 6$, and $1 / 5$ had a very high titer of $\log _{2}$ 7. A hemagglutinating paramyxovirus was isolated from pooled tissues and identified as NDV by RT-PCR and sequence analysis. Phylogenetic comparison of a 374-bp region amplified from the isolate with reference genomes classified the virus as a genotype 1 strain (Fig. 1), with a typical V4-like avirulent fusion protein cleavage site motif of ${ }^{112} \mathrm{GKQGR} \downarrow \mathrm{L}^{117}$.

Illumina MiSeq data was trimmed for adapters, generating 927,966 paired-end reads. De novo assembly was followed by manual BLAST analysis (NCBI; http://blast.ncbi.nlm.nih.gov/Blast.cgi) of large contigs ( $>1 \mathrm{~kb}$ ). A 2309-nucleotide (nt) contig was identified by BLAST analysis as avian gyrovirus type 2, with $99 \%$ nucleotide sequence homology to the strains in GenBank. The contig assembled from 155 reads with an average length of $180 \mathrm{nt}$. Across a 2245-nt multiple sequence alignment (data not shown), pairwise identities between the UP455/13 AGV2 consensus and reference genomes were as follows: AGV2 JQ690763 = 98.08\%; AGV2 NC015396= $99.82 \%$, AGV2 HM590588 = 99.82\%, and HGV FR823283= $95.50 \%$. More-detailed analyses and features of the genomic sequence will be published elsewhere. The genome sequence is deposited in GenBank with accession number KF436510.

To identify or exclude the presence of other pathogens that could be associated with the clinical symptoms observed, an assemble-toreference strategy was used with reference genomes retrieved from GenBank. Influenza A virus (concatenated genome of a recent local H7N1 strain; C. Abolnik, unpubl. data), NDV (JF950510-LaSota, JX524203-V4), infectious bursal disease virus (JX134483), infectious bronchitis virus (JQ088078), West Nile virus (lineage 2, HM147822), avian metapneumovirus (AB548428), Ornithobacterium rhinotracheale (NC018016), and avian encephalomyelitis virus (AY275539) did not produce significant results.

We found 4542 reads mapped to Mycoplasma genomes, but because reads mapped to both Mycoplasma gallisepticum- (NC018412) and Mycoplasma synoviae- (NC007294) specific sequences, the species could not be distinguished from the limited data. Escherichia coli (AE014075) was also detected, with 4589 reads mapped, corresponding to the positive culture results from the air sac swabs. The tissue pool was also positive for avian leukosis virus (ALV) subtype J (CLB908M) with 709 reads mapped and Gallid herpesvirus 2Marek's disease virus (GX0101) with 353 reads mapped.

\section{DISCUSSION}

The respiratory signs observed on postmortem were consistent with chronic respiratory disease (CRD), a common problem in broiler production where mycoplasma is present. ALV of chickens is globally widespread, and the subgroup J detected here is associated primarily with myeloid leukosis in broilers (6). Similarly, MDV is also globally widespread, but the virus usually causes symptoms in birds of 10-20 wk in age, with unilateral paresis and paralysis. We 


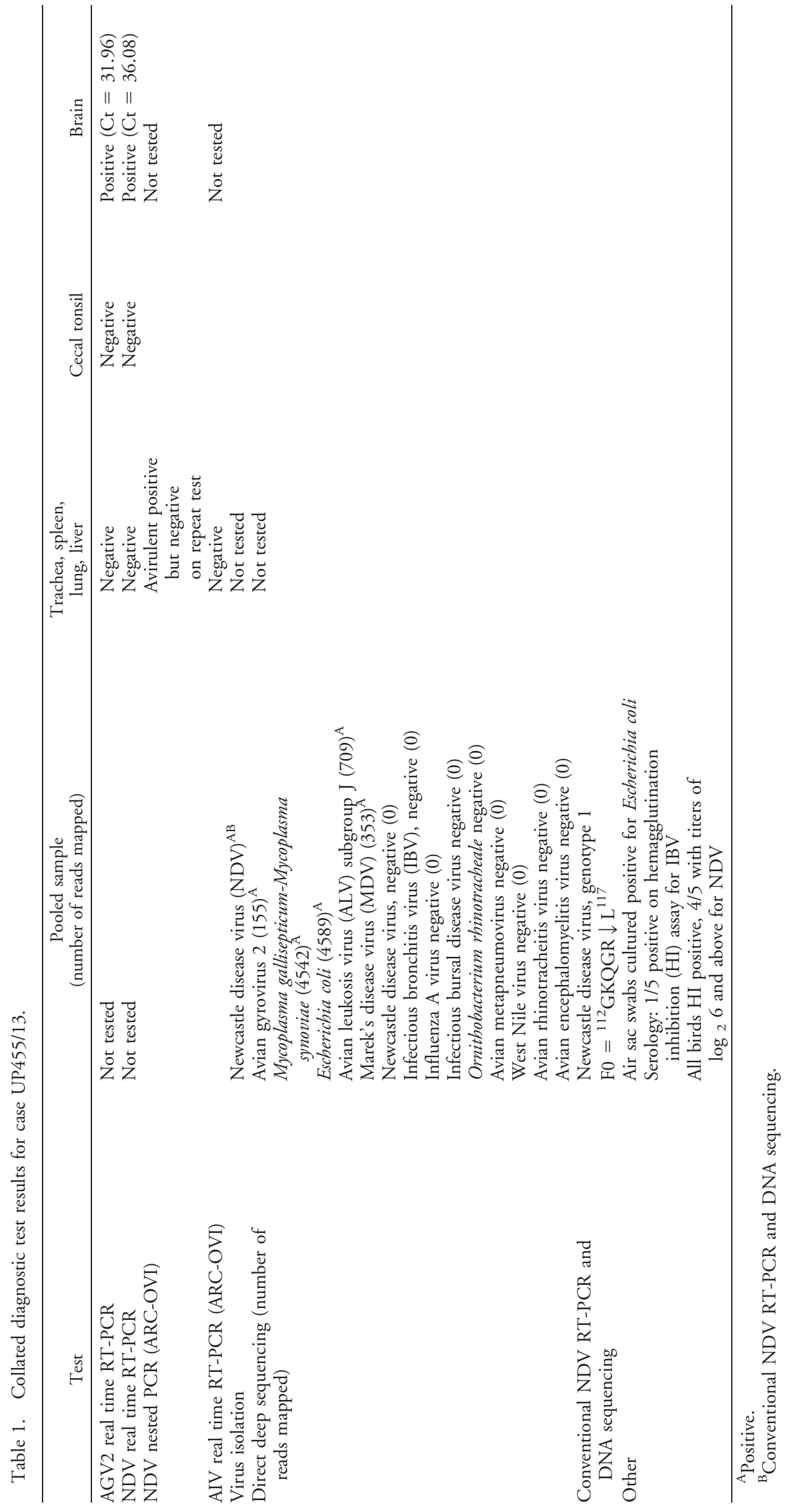




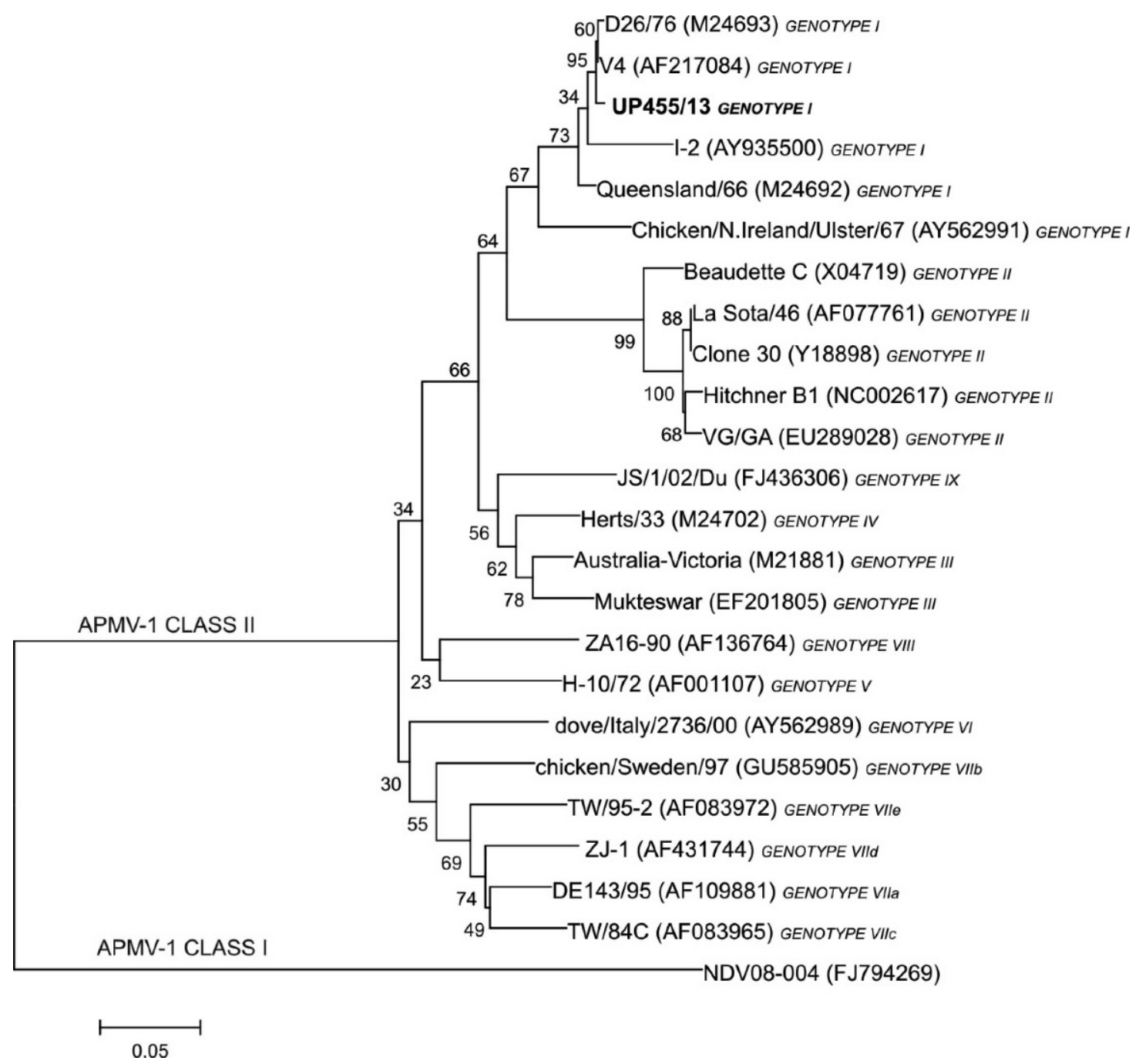

Fig. 1. Phylogenetic analysis of a 374-bp region of the fusion glycoprotein of Newcastle disease virus and classification of strains into genotypes.

consider it unlikely that these viruses were the direct causes of the neurologic symptoms observed. Mycoplasma spp., ALV, and MDV infections are, however, associated with immune suppression and could have contributed to the severity of the disease observed.

AGV2- and NDV-specific nucleic acids were only detected in the brains by RT-PCR and not in other tissue pools. For AGV2 a cycle threshold $(\mathrm{Ct})$ value of 31.96 was obtained and for NDV the Ct value was 36.08, which is a weak-positive result. Separate tissue pools were used for sequencing and virus isolation; thus, it is possible that different proportions of brain tissues were incorporated, which led to successful isolation of virus in eggs despite the failure to detect NDVspecific nucleic acid in the sequence reads. The isolate was typed as a V4-like strain with a typical avirulent fusion protein cleavage site motif of ${ }^{112}$ GKQGR $\downarrow \mathrm{L}^{117}$. Vaccine strains $\mathrm{V} 4$ and $\mathrm{I}-2$ are apathogenic in chickens, and experimental infection studies demonstrated no virus in the brains of chickens by day 7 postvaccination, whereas virus was detected in trachea, lung, cecal tonsil, liver, and spleen, amongst other tissues, at various sampling intervals (13). No genotype 1-type NDV vaccine strains are registered for use in South Africa; all registered vaccine strains are genotype II, typically La Sota, Clone 30, VG/GA, or Hitchner B1-type viruses. The origin of the NDV isolated from case UP455/13 remains unknown but, given the vaccination history and high serum antibody titers against NDV as detected by HI, this appeared to be a field challenge of NDV.
NDV cannot enter host cells in order to replicate unless the precursor viral fusion glycoprotein F0 is activated through cleavage into F1 and F2 by intracellular or extracellular proteases. Virulence of NDV in chickens correlates with cleavage of the F0 protein of the virus; avirulent viruses have a monobasic motif at the F0 cleavage site, ${ }^{112} \mathrm{G}-\mathrm{R} / \mathrm{K}-\mathrm{Q}-\mathrm{G}-\mathrm{R} \downarrow \mathrm{L}^{117}$, and are cleaved extracellularly by trypsin-like proteases found in the respiratory and intestinal tract. Virulent strains have a multibasic amino acid motif at the cleavage site ${ }^{112} \mathrm{R} / \mathrm{G} / \mathrm{K}-\mathrm{R}-\mathrm{Q} / \mathrm{K}-\mathrm{K} / \mathrm{R}-\mathrm{R} \downarrow \mathrm{F}^{117}$ and can be cleaved intracellularly by ubiquitin-like proteases; this results in a systemic infection that is often fatal $(4,8)$. The presence of the UP455/13 NDV with its avirulent F0 sequence ${ }^{112}$ GKQGR $\downarrow \mathrm{L}^{117}$ in the brain might have been explained by perfusion of the tissue during a viremic phase; however; the other organ pools remained NDV-negative on PCR. The possibility of a synergistic effect between AGV2 and avirulent NDV coinfection that facilitates the replication of the latter in the brain must be urgently investigated because live NDV vaccines are widely used. The original detection of AGV2 in a southern Brazilian poultry production unit was made in the sera of 3-wk-old chickens displaying symptoms of apathy and weight loss (10). In the same region, the prevalence of AGV2 in unvaccinated healthy adult backyard chickens varied from 60.4 to $90.7 \%$ between two provinces as assessed by PCR (5). Nine out of $21(42.9 \%)$ brain samples from diseased chickens in the Netherlands displaying neurologic symptoms tested positive for 
AGV2 DNA, and these birds were from commercial poultry farms (5). Details of vaccination were not provided.

Van Rijsewijk and coworkers (10) speculated that AGV2 may have a widespread global distribution, given the geographic distance between the Netherlands and Brazil. The subsequent detection of AGV2 in Hong Kong (3) and now South Africa supports this theory. We intend to assess the prevalence and distribution of AGV2 in our region, and attempts to isolate the AGV2 virus continue because infection studies will be vital to clarify the pathogenicity and organ tropism of AGV2 in chickens as well as its effects in coinfections with the other pathogens identified here. It remains unknown whether AGV2/HGV was originally a human virus that spread to chickens through contact, or a chicken virus that spread to humans through contact or consumption, or indeed whether any significant disease threat is posed to either species. Our results also demonstrate that poultry disease syndromes are complex and that flocks are potentially infected by a variety of pathogens at any given time.

\section{REFERENCES}

1. Abolnik, C., M. de Castro, and J. Rees. Full genomic sequence of an African avian paramyxovirus type 4 strain isolated from a wild duck. Virus Genes 45:537-541. 2012.

2. Abolnik, C., R. F. Horner, S. P. Bisschop, M. E. Parker, M. Romito, and G. J. Viljoen. A phylogenetic study of South African Newcastle disease virus strains isolated between 1990 and 2002 suggests epidemiological origins in the Far East. Arch Virol. 149:603-619. 2004.

3. Chu, D. K., L. L. Poon, S. S. Chiu, K. H. Chan, E. M. Ng, I. Bauer, T. K. Cheung, I. H. Ng, Y. Guan, D. Wang, and J. S. Peiris. Characterization of a novel gyrovirus in human stool and chicken meat. J. Clin. Virol. 55:209-213. 2012.

4. Dortmans, J. C. F. M., G. Koch, P. J. M. Rottier, and B. P. H. Peeters. Virulence of Newcastle disease virus: what is known so far? Vet. Res. 42:122-133. 2011.
5. Dos Santos, H. F., M. B. Knak, F. L. de Castro, J. Slongo, G. A. Ritterbusch, T. A. Klein, P. A. Esteves, A. D. Silva, I. M. Trevisol, E. A. Claassen, L. A. Cornelissen, M. Lovato, A. C. Franco, P. M. Roehe, and F. A. Rijsewijk. Variants of the recently discovered avian gyrovirus 2 are detected in Southern Brazil and the Netherlands, Vet. Microbiol. 155:230-236. 2012.

6. Fadly, A. M. Isolation and identification of avian leucosis virus: a review. Avian Pathol. 29:529-535. 2000.

7. Fuller, C. M., L. Brodd, R. M. Irvine, D. J. Alexander, and E. W. Aldous. Development of an L gene real-time reverse-transcription PCR assay for the detection of avian paramyxovirus type 1 RNA in clinical samples. Arch. Virol. 155:817-823. 2010.

8. Nagai, Y., H. D. Klenk, and R. Rott. Proteolytic cleavage of the viral glycoproteins and its significance for the virulence of Newcastle disease virus. Virology 72:494-508. 1976.

9. Phan, T. G., L. Li, M. G. O’Ryan, H. Cortes, N. Mamani, I. J. Bonkoungou, C. Wang, C. M. Leutenegger, and E. Delwart, E. A third gyrovirus species in human faeces. J. Gen. Virol. 93:1356-1361. 2012.

10. Rijsewijk, F. A., H. F. Dos Santos, T. F. Teixeira, S. P. Cibulski, A. P. Varela, D. Dezen, A. C. Franco, and P. M. Roehe. Discovery of a genome of a distant relative of chicken anaemia virus reveals a new member of the genus Gyrovirus. Arch. Virol. 156:1097-1100. 2011

11. Sauvage, V., J. Cheval, V. Foulongne, M. A. Gouilh, K. Pariente, J. C. Manuguerra, J. Richardson, O. Dereure, M. Lecuit, A. Burguiere, V. Caro, and M. Eloit. Identification of the first human gyrovirus, a virus related to chicken anemia virus. J. Virol. 85:7948-7950. 2011.

12. Schat, K. A. Chicken anemia virus. Curr. Top. Microbiol. Immunol. 331:151-183. 2009.

13. Wambura, P., J. Meers, and P. Spradbrow. Determination of organ tropism of Newcastle disease virus (strain I-2) by virus isolation and reverse transcription-polymerase chain reaction. Vet. Res. Commun. 30:697-706. 2006.

\section{ACKNOWLEDGMENTS}

Diagnostic technicians of the Department of Veterinary Tropical Diseases are thanked for virus isolation, serology, and bacterial culture. 